which her husband could also be buried upon his death. The deceased's widower sought the faculty on the basis that he had been 'tricked' into consenting to the deceased's burial with her mother on the understanding that he could also be buried there, but that that was no longer the case. The remainder of the deceased's family objected to the faculty being granted on the basis that the petitioner had been convicted of sexual offences against the deceased's daughter and others. The chancellor held that the petitioner had not been 'tricked' as he alleged but had simply been honouring the deceased's wishes in burying her with her mother. He found that, had the deceased known the full extent of the petitioner's criminality, it would have been inconceivable that she would have wanted to be interred with the petitioner. He further acknowledged the distress that would be caused to the deceased's family should they be required to mourn the deceased at a grave in which the petitioner was also interred. [RA]

doi:10.1017/So956618X12000154

\title{
R (on the Application of Quila and others) v Secretary of State for the Home Department
}

Supreme Court: Lord Phillips, Baroness Hale, Lords Clarke, Wilson and Brown, October 2011

Immigration rules - right to family life

The Home Secretary appealed the decision of the Court of Appeal concerning rule 277 of the Immigration Rules 1994, which restricts visa applications or sponsorship to those over 21. The Home Secretary argued that the raised age limit for visa applications or sponsorship was intended to protect young people, predominantly women, at risk of forced marriage. Quila was an 18-year-old Chilean man, married to an 18-year-old British wife. Bibi was a Pakistani woman, married to a British national of Asian background. In respect of both marriages, visas to enable the non-British partners to enter or remain in the UK to live with their spouses had been refused. The court held that the refusal to allow foreign spouses to reside in the UK with their new British spouses amounted to an interference with the claimants' right to family life under Article 8 of the ECHR. Given the legitimate purpose of the restriction in protecting young people from forced marriage, the court went on to consider whether that restriction could be justified under Article 8(2). The court considered whether the measures were rationally connected to the objective, whether they were no more than necessary to accomplish that objective, and whether they struck a fair balance between individual and community. It was held that the measures were rationally connected to the objective. The 
crucial questions remained whether the rule really deterred forced marriages and whether its impact on unforced marriages was disproportionate and discriminatory. It was held that there was a lack of evidence that rule 277 would prevent forced marriage and that in some cases it could make the situation more difficult for those forced to marry. In addition, the rule had a discriminatory impact on younger spouses and religious and ethnic groups where people tended to marry younger. The impact on the unforced marriages of younger applicants was a disproportionate interference with their Article 8 rights. The Home Secretary had failed to establish that the measures were no more than necessary to fulfil her objective and that they struck a fair balance between the interest of individuals and the community. The measures could not be justified and the appeal was dismissed. [Catherine Shelley]

doi:10.1017/So956618X12000166

\section{Re St Anne, Turton \\ Manchester Consistory Court: Tattersall Ch, October 2011 Confirmatory faculty - churchyard - bench}

A faculty had been sought (but not yet granted) for the erection of a bench in the churchyard in memory of the petitioner's father (the deceased). After the diocesan advisory committee (DAC) recommended the works, the petitioner had gone on to erect a bench that fell outside the terms of the faculty sought. It was larger than permitted, incorporated two lengthy memorial inscriptions and had a horizontal memorial plaque erected next to it, beneath which the cremated remains of the deceased had been buried without authority. The archdeacon applied for a faculty for the removal of the bench and memorials and the exhumation and re-interment elsewhere of the deceased's remains. The petitioner petitioned for a confirmatory faculty in respect of the bench and memorials but sought the exhumation and re-interment of the deceased's remains as agreed with the archdeacon. The PCC and other parishioners objected to the latter petition. The chancellor, having previously granted a faculty for the exhumation and re-interment of the deceased's remains, refused a confirmatory faculty and directed that the bench and memorials should be removed by the petitioner, or, in the event of his failure to do so, by the churchwardens at the petitioner's expense. The chancellor granted a faculty for the erection of a bench in accordance with the DAC recommendation and in the event that the same was not erected within six months the base to the bench should be removed and the area made good either by the petitioner or at his expense. [RA] 